\section{Conflict and Cooperation in Ant Societies}

\author{
J. Heinze, B. Hölldobler, and C. Peeters* \\ Theodor-Boveri-Institut, Lehrstuhl für \\ Verhaltensphysiologie und Soziobiologie der \\ Universität, D-97074 Würzburg
}

Dedicated to Ernst Mayr on the occasion of his 90th birthday

We review the different levels of reproductive conflict within ant societies. Workers and queens may disagree about sex allocation and the origin of males. Other conflicts arise between queens in multiply queened colonies and occasionally also between workers. These conflicts are resolved either by manipulation, such as sexual deception, changed mating patterns, or pheromonal signaling, or by physical aggression among nestmates. We outline the conditions under which physical aggression occurs and which behaviors are involved in the regulation of reproductive dominance.

* Permanent address: CNRS URA 667, Université Paris Nord, Laboratoire d'Éthologie, F-93430 Villetaneuse
I $\mathrm{n}$ animals that live interdependently in groups, conflicts arise about which individuals produce how many offspring. These conflicts may lead to aggression among group members and strongly shape the structure of the societies of many vertebrates and invertebrates. As a consequence of aggressive interactions, some individuals become dominant and take precedence during feeding or mate selection. Reproductive rank orders have been documented in both vertebrate and invertebrate taxa, with one or a few highly ranked individuals being responsible for most of the reproductive activity within the groups [1].

In the eusocial Hymenoptera - ants and many bees and wasps - an even sharper division of labor occurs between reproductive and sterile females: only one or a few individuals mate and lay fertilized eggs, whereas the majority of the female nestmates do not reproduce and instead forage, construct the nest, defend the territory, and nurse the offspring of the reproductives $[2,3]$. In ants, the separation of roles is typically associated with a clear morphological specialization to the respective tasks. Thus, queens are phenotypically adapted for dispersal, mating, and egg-laying, whereas workers are adapted for the tasks of colony maintenance.

Compared to societies of, say, primates or fish, insect colonies, and especially those of ants, appear to be rather harmonious and free of overt aggression (Fig. 1). This, however, is not always the case. In this review we will examine the different levels of reproductive conflict in ant colonies and the conditions under which disagreement among nestmates leads to either aggression or manipulation.

\section{The Superorganism}

The division of labor between ant queens and workers and among different worker subcastes can reach extraordinary extremes of complexity. In many aspects it 


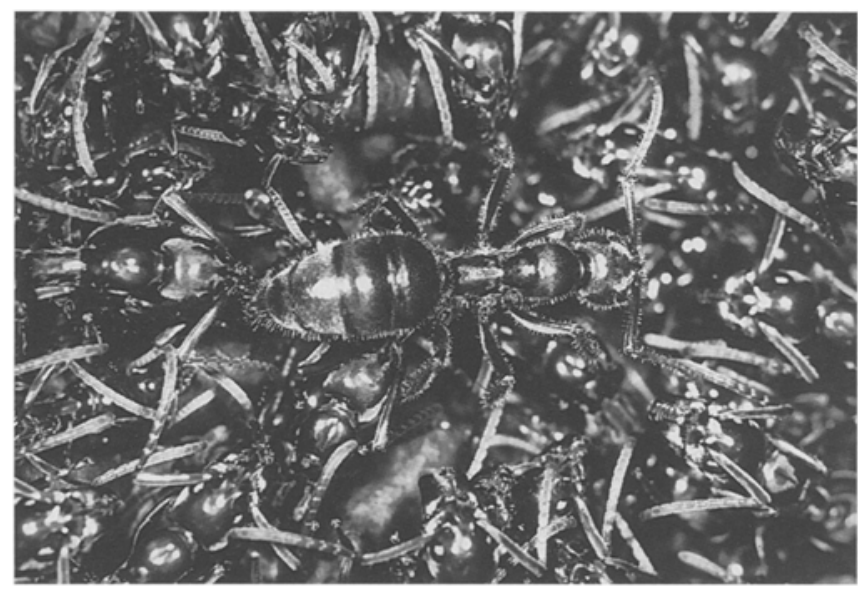

Fig. 1. The queen of Megaponera foetens is surrounded by a retinue of workers all with their head directed towards the queen. The attractiveness of the queen is caused by chemical signals released from epidermal glands (from [73])

appears more appropriate to treat the colony as a functional unit rather than a group of individuals, and it is the colony which must be examined in order to understand the biology of a eusocial species. Consider, for example, the great colonies of African driver ants. Their raiding column spreads like the pseudopodium of a giant amoeba across tens of meters of ground. A closer look reveals it to comprise a mass of several million workers running in concert from the subterranean nest. Groups of foragers cooperate in transporting large prey objects, while large-headed workers station themselves alongside the raiding column with their strong mandibles pointing upwards, ready to defend it [4]. Division of labor is highly efficient also in the leaf-cutter ants of the genus Atta. Different size classes of workers are tailored to the special needs of harvesting, retrieving, and processing the leaves on which fungus is cultured [5]. In these and other cases, not the individual ants, but the colony as a whole competes with other such entities for resources and territorial space [6]. Furthermore, the colony maintains a constant ratio of different worker subcastes and age classes and thus may show an adaptive demography $[7,8]$. Ant colonies have therefore been compared with multicellular organisms and termed "superorganisms" [9]. The key process in the development of an organism is morphogenesis, the steps by which cells change their shape and chemistry and arrange themselves to build the organism. Similarly, the key process in the ontogeny of a superorganism is sociogenesis, which consists of the steps by which individuals undergo changes in caste and behavior to build the insect society. The similarities between the rules and algorithms of morphogenesis and sociogenesis are striking [10].
Nevertheless, there is a fundamental difference between multicellular organisms and ant societies: All cells of an organism are genetically identical, but considerable genetic heterogeneity exists among the individuals in an ant colony. Even if they all are the progeny of a single pair of outbred parents, female nestmates in an ant colony share only $75 \%$ of their genes by descent, and multiple mating or the presence of several queens per colony further decrease nestmate relatedness [11, 12].

\section{Levels of Conflict in Ant Colonies}

As a consequence of the genetic heterogeneity within colonies, the reproductive interests of nestmates are seldom identical [12-14]. Specifically, conflict is expected between the queen and the workers over two major aspects of reproduction: the relative investment in the sexes and the source of males.

In Hymenoptera, males are haploid and develop from unfertilized eggs, while females are diploid and develop from fertilized eggs [15]. As a consequence of haplodiploid sex determination, in a colony with a singly mated queen (monogyny and monoandry), workers share $75 \%$ of their genes by descent with their sisters but only $25 \%$ with their brothers (Fig. 2). Workers will therefore be selected to invest three quarters of the colony's reproductive efforts in the production of sister sexuals and only one quarter in raising brothers. The queen, however, being equally related to her sons and daughters, is selected to enforce equal investment in both sexes of her reproductive offspring $[16,17]$.

In addition, workers have the option of producing their own sons. Though they typically cannot mate and their ovaries are more or less rudimentary, in many species they are capable of laying unfertilized eggs, which may develop into haploid males $[3,18]$. In monogynous and monoandrous colonies the workers share $50 \%$ of their genes with their own sons and $37.5 \%$ with their nephews, as compared to $25 \%$ shared with their brothers. Selection acting on workers would therefore favor the substitution of sons or nephews for brothers in the reproductive brood. The queen, on the other hand, shares $25 \%$ of her genes with her grandsons and $50 \%$ with her own sons, hence, she should try to prevent workers from laying eggs and rather have them concentrate on her own offspring (Fig. 2).

As each worker is more related to her own sons than to her nephews conflicts also arise over which of the workers will lay eggs and which continue to take care of the nest [18]. Another level of conflict exists in colonies that contain several queens. It has long been known that queens exhibit the highest egg-laying rate when 


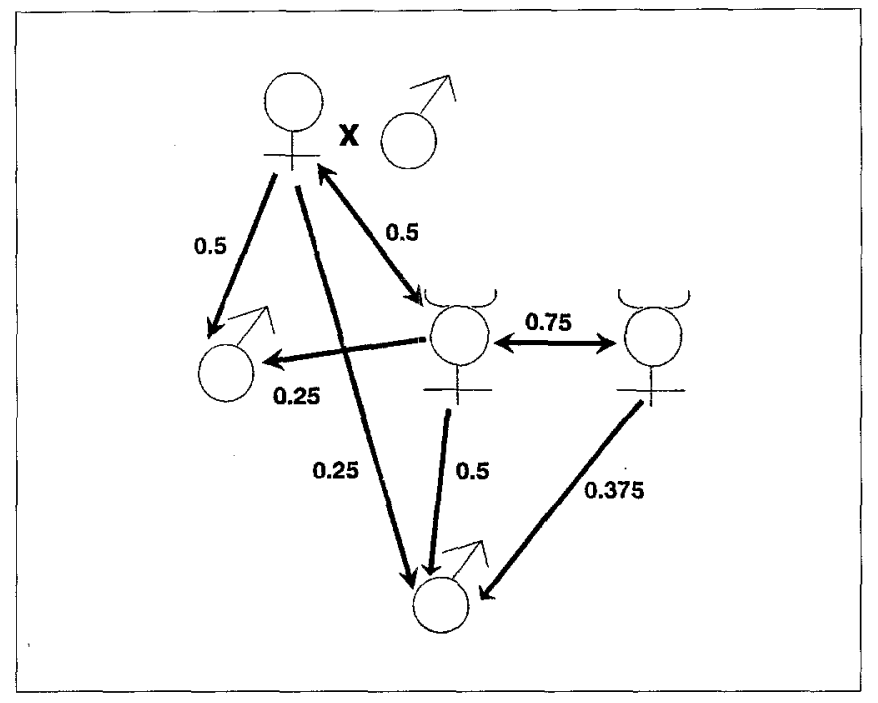

Fig. 2. Genetic relationships among nestmates in an ant colony which contains only one, singly inseminated queen (monogyny and monoandry, and assuming that the parents are not related). The values given here are the life-for-life relatedness, i.e., what fraction of the donor's genes is identical by descent with any of the recipients $[8,12,71,74]$ Arrows point towards the recipient. Note that due to haplodiploidy the fraction of a father's genes identical by descent with its daughter's genotype is not the same as the fraction of a daughter's genes identical by descent with her father's genotype. Relationships with the male being the donor are not considered here. A life-for-life value of 0.75 means that an individual shares $75 \%$ of its genes by descent with a recipient. Workers ( $\varnothing$ ) thus share $75 \%$ of their genes by descent with their sisters, $25 \%$ with their brothers, $50 \%$ with their own sons, and $37.5 \%$ with their nephews

they occur singly in the colony [19]. Hence, a queen that tolerates a rival queen immediately reduces her own direct reproductive success. In many species, several queens may nevertheless permanently coexist [3, 20] and they apparently ignore each others' presence [21].

Thus, disagreement exists in ant societies, especially between the queen and the workers. Many case studies show that these conflicts are resolved by either manipulation or aggression.

\section{Sexual Deception, Multiple Mating, and Polygyny}

Sex allocation conflict has been extensively reviewed (e.g., [16]) and will not be discussed here in detail. Analyzing the dry weights of male and female sexuals, Trivers and Hare [12] obtained sex ratios close to the hypothetical 1:3, suggesting worker control. However, new theoretical and empirical approaches have shown that sex allocation is more complicated than it appeared from these data. To manipulate the sex ratio and also to selectively replace brothers with their own sons or nephews, workers must be able to identify the sex of larvae or eggs. Worker aggression towards male larvae has once been reported [22], but recent experiments failed to demonstrate discriminatory capabilities [23]. Perhaps it is the queen's strategy to win the queen-worker conflict by hiding the sex of her offspring from the workers. This strategy of sexual deception, though "dishonest", may be evolutionarily stable $[24,25]$.

Queens could also minimize conflict with their workers by mating with several males. Multiple insemination (polyandry, [26]) affects the reproductive interests of workers relative to both sex allocation and the origin of males. Due to polyandry, workers are on average less closely related to each other and to the female reproductives they are helping to rear. But because males arise from unfertilized eggs the relatedness of a worker to her mother's male offspring is not affected by paternity patterns in the colony. With increasing number of matings and if sperm from different males is used randomly by the queen, the average percentage of genes the workers share by descent with their sisters approaches that shared with their brothers. In such situations, the queen and the workers should initially favor roughly equal investment in female and male reproductives $[27,28]$. However, when polyandrous colonies spread in the population, workers should prefer queen-biased sex ratios if their queen has mated with a below-average number of males, but malebiased sex ratios if she has mated with an aboveaverage number of males $[17,29]$. Ultimately, a continuing "arms race" could result, with mate numbers and the sex ratio preferences of workers coevolving [30]. That workers can bias sex ratios in response to relative relatedness asymmetries was recently demonstrated in the wood ant, Formica truncorum: Colonies with multiply mated queens invested more strongly in males [31].

If workers are not able to distinguish between the sons of a full sister $(37.5 \%)$ and the sons of a half sister $(12.5 \%)$, they are expected to prefer to rear their mother's sons $(25 \%)$ rather than worker-produced males [27]. In this case, not only the queen should attempt to inhibit worker reproduction, but also the worker's should "police" their nestmates and prevent them from raising sons $[32,33]$. Honeybee workers indeed remove worker-laid eggs from brood cells [34]. The presence of multiple, closely related queens within a colony (polygyny) can similarly reduce queen-worker conflict concerning male production $[12,28]$. In polygynous or polyandrous societies, the interests of queens and workers might thus converge [28]. 


\section{Pheromonal Control}

In addition to attempting to "win" the queen-worker conflict by altering the workers' reproductive interests, queens could chemically prevent workers from laying eggs. Experimental results suggest that workers' ovaries are inhibited in the presence of the queen and that this is mediated by queen pheromones. To list only a few examples, in queenright colonies of Aphaenogaster cockerelli, Plagiolepis pygmaea, or Oecophylla longinoda, workers produce only trophic eggs which are eaten by the queen or other nestmates. After removal of the queen they lay both trophic and viable eggs, which develop into males [35]. Whether queen pheromones are mechanisms of worker domination or mechanisms for workers to monitor the presence of their queen is still unclear. For honeybees, where the sole queen is typically multiply inseminated, and where it is therefore in the interest of both the workers and the queen that the workers remain sterile as long as the queen is present, Seeley [33] has convincingly argued for the monitoring hypothesis. More recently, Keller and Nonacs [24] have suggested that queen pheromones are always "honest signals", even in monogynous and monoandrous colonies, and that it is ultimately in the workers' own interest if they respond to the signal by refraining from reproduction. The argumentation somewhat parallels the debate on parental manipulation: Signals which manipulate the workers contrary to their own fitness interests are not evolutionarily stable, because selection would favor the evolution of countermeasures against this manipulation in the workers. This assumes, however, that protection against inhibition can easily evolve by one or a few mutational steps. If queen pheromones interfere with the workers' hormonal regulation, physiological constraints might make the evolution of protection unlikely. However, too little is known about the mechanism of how queen signals interact with worker fertility to answer this question.

Given that in some ant species queens attack those workers whose ovaries are most developed (see below), queen signals could initially have been a chemical extension of physical aggression. Pheromones might thus not only signal the presence of a queen, but also her ability to dominate her workers by physical aggression. In large ant societies, a signaling pheromone emitted by the dominant queen obviously replaced direct physical domination and has an inhibitory function [36]. However, to respond to this signal and forgo reproduction is probably also to the advantage of the workers, because in advanced societies with a large queenworker polymorphism the workers are very inefficient egg layers in comparison to the queen. Data on the controlling effects of the queen have been used to support the hypothesis that parental manipulation was involved in the evolution of eusociality [37].

Queen signals might act also on other levels of reproductive conflict. Probably mediated by pheromones, the presence of the queen prevents alate virgin queens from shedding their wings and becoming fertile [38], and inhibits the adoption of rival queens [39]. In colonies with several queens, mutual inhibition by queen pheromones may cause the observed decrease in individual reproduction ([40], but see [41]). In the Cape honeybee, fertile workers produce queen pheromones [42], but whether fertile ant workers pheromonally prevent nestmates from reproducing is unknown.

\section{Fighting and Dominance}

Thus, it appears that reproductive conflict in ant societies is diminished or resolved mainly by manipulation, such as multiple mating, sexual deception, or pheromonal regulation. True, the societies of a majority of species function without any overt friction, but recent investigations reveal that physical aggression among nestmates occurs far more commonly than previously thought.

When new colonies are initiated by several queens, after emergence of the first workers, severe fighting among foundresses soon sets an end to the initially peaceful cooperation [43]. During this stage, workers are occasionally involved in killing or expelling supernumerary queens. In some species, however, workers may also attack and execute some of the queens in mature, polygynous colonies, thus probably limiting the number of queens $[21,44]$.

A detailed investigation of the social organization of various other species, especially from the tribe Leptothoracini (subfamily Myrmicinae) and the subfamily Ponerinae, revealed a bewildering array of aggressive interactions among nestmates. Here, fighting may occur between queens and workers, among queens, and among workers. The behaviors which are exhibited during antagonistic encounters range from highly stereotyped antennal duels or climbing over the head and thorax of an opponent to violent pulling, biting, and occasionally stinging (Figs. 3-5). In addition, nestmates compete by eating each other's eggs.

Queens of Protomognathus americanus attack and beg food preferentially from those workers in their retinue which have the greatest ovarian development, thus inhibiting them from reproducing [45]. In several species of Leptothorax and the ponerine Pachycondyla, workers form hierarchies by antennation bouts and biting, and the top-ranking worker may lay eggs even in the presence of the queen [46]. In the slave-maker Harpagoxe- 

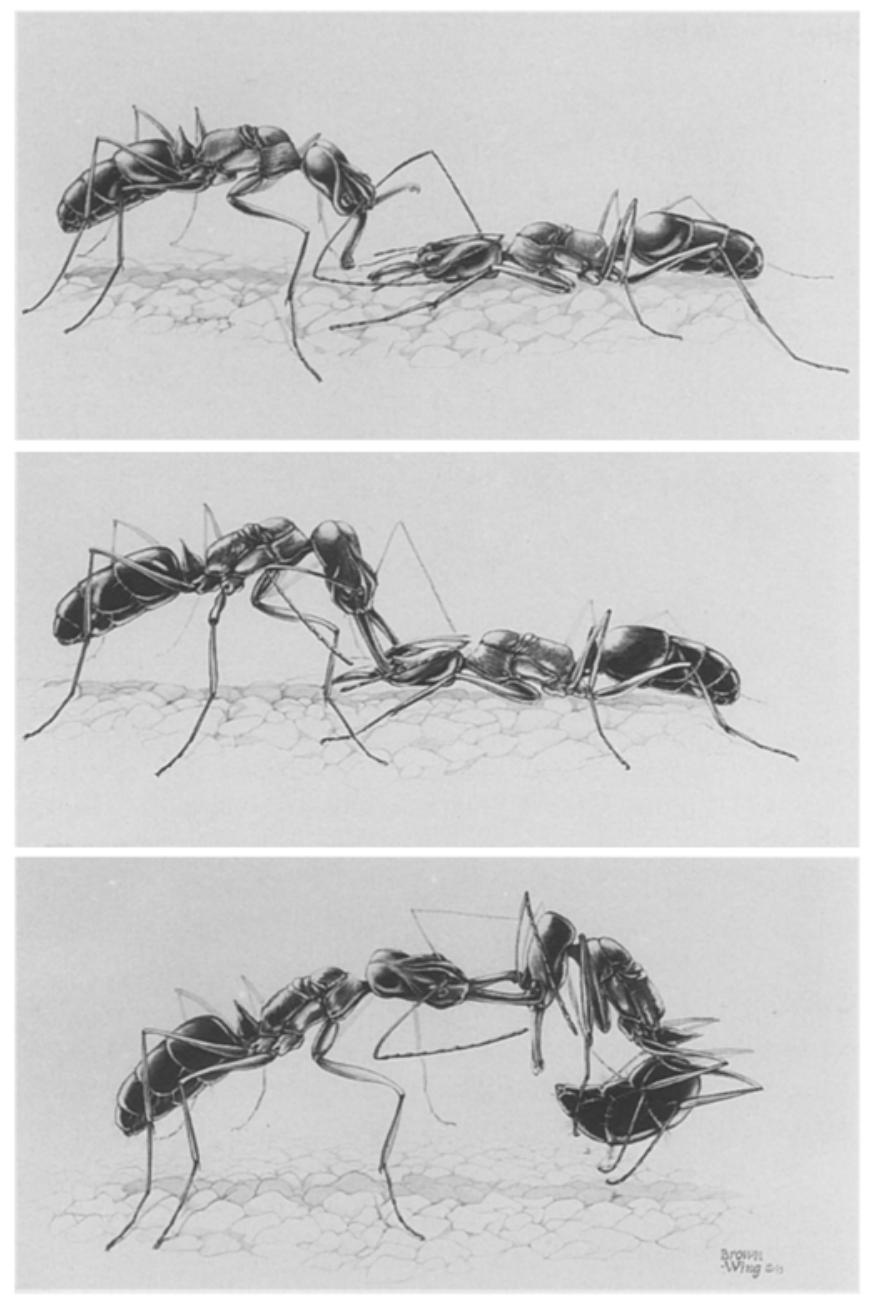

Fig. 3. Sequence of dominance displays between queens of Odontomachus chelifer. Above: The dominant queen (left) beats the head of the crouching subordinate with her antennae, who responds by pulling back the antennae and closing the mandibles. Middle: The dominant queen changes to a more aggressive posture, seizing and pulling the subordinate on the head. Bottom: The dominant queen escalates her aggressive behavior by lifting the opponent up. The latter behaves very submissively by assuming a pupal posture (based on [53] from [75], drawing by $K$. Brown-Wing)

nus sublaevis, workers not only compete with conspecific nestmates [47] but also dominate Leptothorax slave workers, which they have pillaged as pupae from nearby nests. They thus appear to prevent the Leptothorax workers from rearing sons, which would be of no value whatsoever to the Harpagoxenus slave-makers [48].

Queens in colonies of the palaearctic Leptothorax gredleri [49] and nearctic Leptothorax sp. A [50] engage in aggressive interactions directly after hibernation, by which they determine their position in dominance hierarchies. Interactions may escalate into severe mandible and sting fights, when the combatants are of similar

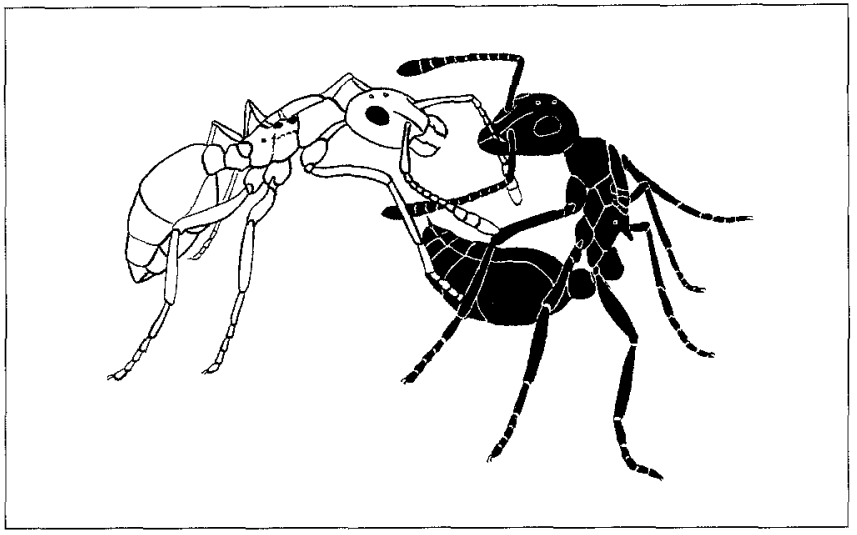

Fig. 4. Mandible and sting fight between two nestmate queens of Leptothorax acervorum from Alaska. The white queen on the left attacked the black queen with opened mandibles and violent beating with the antennae. Rather than assuming a subordinate posture, the black queen seized one of the attacker's antennae, bent her gaster towards her with the sting exposed (drawing by J. H., based on video recordings)

rank (Fig. 4). During these encounters occasionally one or both of the fighting queens are injured or killed. One third of $L$. gredleri queens collected in a population near Würzburg lacked parts of their legs or antennae, probably due to fighting [49]. Queen antagonism may strongly affect the social organization of the colony. After prolonged stinging and biting among queens, workers often pick up larvae and leave the nest. In Formicoxenus provancheri it was observed that queenqueen aggression induced colony fragmentation, i.e., a subordinate queen and several workers emigrated out of the main nest [51].

In leptothoracine ants, fighting among queens eventually leads to a monopoly of reproduction by a single queen (functional monogyny [52]). In contrast, in colonies of the neotropical ponerine Odontomachus chelifer [53] and the nearctic formicine Camponotus planatus [54], several queens may lay eggs, though egg-laying rates appear to be correlated with the queens' hierarchy rank.

Bizarre dominance systems have been discovered in several ponerine ants. Queens do not exist in the palaeotropical genus Diacamma; all females are morphologically workers. When emerging from their pupal cocoons they bear tiny, bud-like thoracic appendages called gemmae [55]. In D. australe, only one worker in each colony retains the gemmae, and she is always mated and monopolizes egg-laying. This mated worker (gamergate) bites off the gemmae of her nestmates soon after they emerge. Mutilation makes future sexual activity impossible and thus permanently prevents mutilated workers from producing diploid offspring. Nonetheless, they remain capable of producing males and begin to lay eggs a few days after experimental 
removal of the gamergate. In recently orphaned worker groups of two Diacamma species from Japan and Malaysia, aggressive interactions and egg cannibalism eventually lead one mutilated worker to monopolize the production of males [56]. Similarly, in other ponerine ants in which a morphological queen caste does not exist, gamergates and workers may fight for dominance [57].

Equally spectacular as the Diacamma dominance system is the pattern recently documented in the Indian ponerine ant Harpegnathos saltator (C. Peeters, B. Hölldobler, in preparation). New colonies of Harpegnathos are founded in a conventional way by dealate, inseminated queens. As the colony increases in size, a number of workers mate during the annual period of male activity. Some of these will begin to reproduce when the founding queen dies (queen longevity appears to be unusually short in this species). Once the colonies have become queenless, several gamergates coexist and they all have equally active ovaries. This polygynous situation is reflected by the nonlinear nature of the hierarchy in $H$. saltator. Such a hierarchy is established by twofold interactions among a proportion of the workers (both virgin and mated) in particular, biting of body parts followed by violent jerking, or highly ritualized antennal tournaments (Fig. 5). The latter involve individuals of similar status, while unilateral attacks apparently occur between workers whose status has already differentiated. Attacks are never observed among gamergates; these are initially involved in antennal tournaments, but they stop once the hierarchy has become stable. Mated workers who have subordinate status exhibit undeveloped ovaries, and they serve as nurses or foragers.

In colonies of yet another ponerine ant, Pachycondyla tridentata, almost all workers were found to be inseminated. Workers and queens compete aggressively for reproduction but the top-ranking individual is not always a queen [58].

Typically, aggression among nestmates serves to establish dominance hierarchies; once these are stable and one or a few top-ranking individuals monopolize reproduction, fighting stops or at least becomes infrequent. When the dominant individuals die or are removed, however, fighting soon resumes. Subordinates are probably monitoring the presence of chemical signals emitted by dominants. These signals, however, do not always prevent subordinates from attempting to become fertile in the presence of a dominant queen. Subordinate queens of Leptothorax sp. A which are not given the choice to emigrate may start to develop eggs, but are attacked and killed by workers.

A surprising and still little understood variant of intracolonial aggression has been discovered in the fire ant,

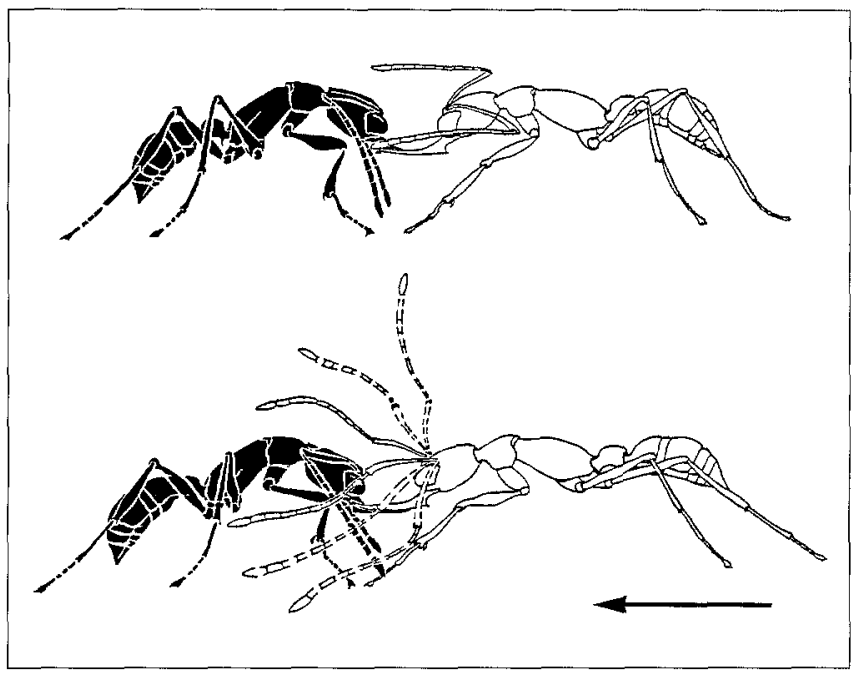

Fig. 5. Dominance interaction between two workers of Harpegnathos saltator: ritualized antennal tournament. The white individual moves forward (arrow) and rapidly beats with its antennae the black individual, which retreats. Seconds later the situation is reversed and the black individual moves forward. This alternates several times during one tournament bout (drawing by $\mathrm{M}$. Obermayer)

Solenopsis invicta: Workers in polygynous colonies execute all adopted queens of a specific genotype, though these exhibit the greatest reproductive development [59].

\section{When Does Conflict Lead to Physical Aggression?}

Why do queens of some species dominate their workers with biting and pulling, while queens of other species rely on pheromones? Why do nestmate workers or queens fight in some species, but never in others? As mentioned earlier, queens may have several strategies to reduce conflict. Furthermore, if nestmate antagonism is costly by leading to a deterioration in colony performance, physical conflict is selected against [14, $24,32,60]$.

From empirical data, two generalizations can be made on the occurrence of aggression in ant societies. Firstly, dominance hierarchies appear to be restricted to species with comparatively small colonies, such as Leptothorax and various ponerines. Such societies consist of only a few dozen, rarely several hundred individuals, of which only a small proportion engage in aggressive interactions. In larger colonies with hundreds or thousands of competing individuals, physical aggression is probably no longer suitable to regulate reproduction, due to ineffectiveness and high costs to the individual [61]. 
Secondly, physical antagonism occurs especially in those cases where the average numerical ratio between reproductives and nonreproductives in the colony is high. This is the case when queen-worker dimorphism is limited and workers have a high reproductive potential. Aggression thus is common in permanently queenless ponerine ants, where all workers are potentially capable of mating and of laying fertilized eggs [55-58, 62]. In functionally monogynous Leptothorax species, due to ecological constraints on solitary colony founding, high numbers of young queens do not disperse after mating but return into their maternal colonies. Under these conditions, stable reproductive hierarchies and fighting among nestmate queens may evolve [61, 63]. In closely related species, in which dispersal risks and average queen numbers per colony are lower, nestmate queens do not fight.

Finally, in slave-makers such as Harpagoxenus or Protomognathus, slaves do all the daily maintenance work, including care of the slave-maker's brood. Hence, slavemaker workers probably cannot manipulate the sex ratio in the queen's brood $[47,64]$. This might promote worker reproduction; indeed, slave-maker workers often have larger ovaries than workers in related nonparasitic species [65].

\section{Social Hierarchies and Reproductive Success}

Fighting among nestmates typically leads to reproductive hierarchies, in which rank and egg-laying rate are correlated. Egg-laying rate, however, is not a good indicator of reproductive success [66]. Eggs may be eaten or fed to larvae $[3,67]$ or they may preferentially develop into nonreproductive workers rather than sexuals [68]. It is only reasonable to conclude that the highest-ranking individual in the colony has also the highest reproductive success when this individual completely monopolizes egg laying. Relatedness estimates based on allozyme markers confirm that female pupae reared in colonies of Leptothorax $\mathrm{sp}$. A are offspring of the single dominant queen (Heinze, unpubl.). However, in cases where several high-ranking queens, gamergates, or workers lay eggs, only maternity analyses with highly variable genetic markers can elucidate how reproductive success and social rank are interrelated. Such analyses might also reveal the existence of reproductive hierarchies in species from which antagonism among queens appears to be absent. In two such species, Solenopsis invicta [68] and Leptothorax acervorum (Heinze, Lipski, Hölldobler, unpubl.), there is some evidence that queens in polygynous colonies do not equally contribute to the female sexual progeny.

\section{Reproductive Conflict and the Superorganism}

What, then, with all the hidden or open conflicts uncovered in ant societies, remains of the superorganism as a biological concept? Following an almost complete demise in the 1960s and 1970s, the superorganism has again become fashionable as a unit of both function and selection. To several authors, however, the phenomenon itself still remains vaguely or controversially defined [69]. According to Wilson and Sober [70], a group will show superorganismic properties when between-group selection is larger than within-group selection; when natural selection operates strongly within groups, these cease to be superorganisms. This rather extreme definition of superorganisms would disqualify those insect societies in which nestmates compete for reproduction, including the above-mentioned ants. Natural selection apparently acts on several levels. For example, such ant colonies that employ the most efficient foraging and territorial strategies will produce more sexuals than less efficient colonies, even though within the colony workers compete for egg-laying rights. However, if colony efficiency is increased by interactions among genetically different lineages of nestmates, colony phenotypes cannot be selected directly, but only indirectly at the individual level via the mating strategy of the queen. If genotypic diversity is advantageous, then polyandrous queens, or queens which tolerate the adoption of additional reproductives, may have greater reproductive success [71]. Which properties of ant societies are selected at the individual, kin, or colony level and which are self-organized consequences emerging from the basic social structure [72], is unclear.

At the very least, the superorganism can be seen as a primarily heuristic device, a functional concept which helps to study the role of ant colonies in ecosystems. To treat the colony as an individual may often facilitate the description and analysis of territorial conflicts within and between species, complex patterns of division of labor and social communication, or foraging strategies. The fine structure of a colony in which workers unanimously defend their territory against conspecific competitors may simultaneously be strongly shaped by their selfish reproductive behavior.

T. D. Seeley, Ithaca, NY, and A. F. G. Bourke, London, made helpful comments on the manuscript. This work was made possible by grants from the Deutsche Forschungsgemeinschaft (Leibniz-Prize to B. H. and SFB 251). 
1. Wilson, E. O.: Sociobiology: the New Synthesis. Cambridge, MA: Belknap Press of Harvard Univ, Press 1975; Keller, L., Reeve, H. K.: Trends Ecol. Evol. 9, 98 (1994)

2. Wilson, E. O.: The Insect Societies. Cambridge, MA: Belknap Press of Harvard Univ. Press 1971

3. Hölldobler, B., Wilson, E. O.: The Ants. Cambridge, MA: Belknap Press of Harvard Univ. Press 1990

4. Gotwald, W. H., in: Social Insects, Vol. 4, p. 157 (H. R. Herman, ed.). New York: Academic Press 1982

5. Wilson, E. O.: Behav. Ecol. Sociobiol. 7, 143, 157 (1980); 14, 47, 55 (1983)

6. Hölldobler, B.: ibid. 1, 3 (1976); Hölldobler, B., Lumsden, C. J.: Science 210, 732 (1980)

7. Johnston, A. B., Wilson, E. O.: Ann. Entomol. Soc. Am. 78,8 (1985)

8. Oster, G. F., Wilson, E. O.: Caste and Ecology in Social Insects. Princeton: Princeton Univ. Press 1978

9. Wheeler, W. M.: J. Morphol. 22, 3007 (1911); The Social Insects: Their Origin and Evolution. London: Kegan Paul, Treanch, Trubner and Co. 1928

10. Wilson, E. O.: Science 228, 1489 (1985); Lumsden, C. J.: J. Theor. Biol. 95, 749 (1982)

11. Hamilton, W. D.: ibid. 7, 1 (1964); Ann. Rev. Ecol. Syst. 3, 193 (1972); Crozier, R. H.: Annu. Rev. Entomol. 22, 263 (1977)

12. Trivers, R. L., Hare, H.: Science 191, 249 (1976)

13. West-Eberhard, M. J., in: Natural Selection and Social Behavior, p. 3 (R. D. Alexander, D. W. Tinkle, eds.). New York: Chiron 1981; Seger, J., in: Behavioural Ecology, p. 338 (J. R. Krebs, N. B. Davies, eds.). London: Blackwell 1991

14. Ratnieks, F. K. W., Reeve, H. K.: J. Theor. Biol. 158, 33 (1992)

15. Crozier, R. H., in: Social Insects, Vol. 1, p. 223 (H. R. Herman, ed.). New York: Academic Press 1979; Cook, J. M.: Heredity 71, 421 (1993)

16. Nonacs, P.: Quart. Rev. Biol. 61, 1 (1986); in: Queen Number and Sociality in Insects, p. 110 (L. Keller, ed.). Oxford: Oxford Univ. Press

17. Pamilo, P.: Am. Nat. 137, 83 (1991)

18. Bourke, A. F. G.: Quart. Rev. Biol. 63, 291 (1988); Choe, J. C., in: Advances in Myrmecology, p. 163 (J. C. Trager, ed.). Leiden: Brill 1988

19. Wilson, E. O.: Ann. Entomol. Soc. Am. 67, 781 (1974); Mercier, B., Passera, L., Suzzoni, J.-P.: Insectes Soc. 32, 335 (1985); 32, 349 (1985); Keller, L.: Anim. Behav. 36, $159(1988)$

20. Buschinger, A., in: Sozialpolymorphismus bei Insekten, p. 862 (G. H. Schmidt, ed.). Stuttgart: Wiss. Verlagsges. 1974; Hölldobler, B., Wilson, E. O.: Naturwissenschaften 64, 8 (1977); Frumhoff, P. C., Ward, P. S.: Am. Nat. 139, 559 (1992); Keller, L. (ed.): Queen Number and Sociality in Insects. Oxford: Oxford Univ. Press 1993

21. Heinze, J., in: ibid., p. 334

22. Brian, M. V.: Biol. Rev. 55, 379 (1980)

23. Nonacs, P., Carlin, N. F.: Proc. Nat. Acad. Sci. USA 87, 9670 (1990)

24. Keller, L., Nonacs, P.: Anim. Behav. 45, 787 (1993)

25. Nonacs, P., in: Evolution and Diversity of Sex Ratio in Haplodiploid Insects and Mites, p. 384 (D. L. Wrensch, M. A. Ebbert, eds.). New York: Chapman and Hall 1992
26. Page, R. E., Metcalf, R. A.: Am. Nat. 119, 263 (1982); Cole, B. J.: Behav. Ecol. Sociobiol. 12, 191 (1983)

27. Starr, C. K., in: Sperm Competition and the Evolution of Animal Mating Systems, p. 428 (R. L. Smith, ed.). Orlando: Academic Press 1984; Moritz, R. F. A.: Behav. Ecol. Sociobiol. 16, 375 (1985); Woyciechowski, M., Łomnicki, A.: J. Theor. Biol. 128, 317 (1987)

28. Pamilo, P.: Am. Nat. 138, 412 (1991)

29. Boomsma, J. J., Grafen, A.: Evolution 44, 1026 (1990); Boomsma, J. J., Grafen, A.: J. Evol. Biol. 3, 383 (1991)

30. Queller, D. C.: Am. Nat. 142, 346 (1993)

31. Sundström, L.: Nature 367, 266 (1994)

32. Ratnieks, F. L. W.: Am. Nat. 132, 217 (1988)

33. Seeley, T. D.: Behav. Ecol. Sociobiol. 5, 391 (1979); Honeybee Ecology: a Study of Adaptation in Social Life. Princeton: Princeton Univ. Press 1985

34. Ratnieks, F. L. W., Visscher, P. K.: Nature 342, 796 (1989); Ratnieks, F. L. W.: Behav. Ecol. Sociobiol. 32, 191 (1993)

35. Hölldobler, B., Carlin, N. F.: Psyche 96, 131 (1989); Passera, L.: Insectes Soc. 27, 212 (1980); Hölldobler, B., Wilson, E. O.: Ann. Entomol. Soc. Am. 76, 235 (1983)

36. West-Eberhard, M. J.: Proc. 8th Int. Congr. Int. Union Study Social Insects, p. 223 (1977); Hölldobler, B., in: Insect Communication, p. 349 (T. Lewis, ed.). London: Academic Press 1984

37. Alexander, R. D.: Ann. Rev. Ecol. Syst. 5, 325 (1974); Michener, C. D., Brothers, D. J.: Proc. Nat. Acad. Sci. USA 71, 671 (1974)

38. Fletcher, D. J. C., Blum, M. S.: Science 212, 73 (1981); J. Comp. Physiol. 153, 467 (1983); Passera, L., Aron, S.: Psyche 100, 51 (1993)

39. Fletcher, D. J. C., Blum, M. S.: Science 219, 312 (1983)

40. Vargo, E. L.: Behav. Ecol. Sociobiol. 31, 205 (1992)

41. Bourke, A. F. G.: Anim. Behav. 45, 501 (1993)

42. Crewe, R. M., Velthuis, H. H. W.: Naturwissenschaften 67, 467 (1980)

43. Waloff, N.: Insectes Soc. 4, 391 (1957); Bartz, S., Hölldobler, B.: Behav. Ecol. Sociobiol. 10, 137 (1982); Hölldobler, B., Carlin, N. F.: ibid. 18, 45 (1985); Rissing, S. W., Pollock, G. B.: Anim. Behav. 34, 226 (1986)

44. Keller, L., Passera, L., Suzzoni, J.-P.: Physiol. Entomol. 14, 157 (1989)

45. Franks, N. R., Scovell, E.: Nature 304, 724 (1983)

46. Cole, B. J.: Science 212, 83 (1981); Behav. Ecol. Sociobiol. 18, 165 (1986); Oliveira, P. M. S., Hölldobler, B.: ibid. 27, 385 (1990)

47. Bourke, A. F. G.: ibid. 23, 323 (1988)

48. Heinze, J., Ortius, D., Kaib, M., Hölldobler, B.: ibid. (in press)

49. Heinze, J., Lipski, N.: Naturwissenschaften 77, 493 (1990); Heinze, J., Lipski, N., Hölldobler, B.: Ethology 90, 227 (1992)

50. Heinze, J., Smith, T. A.: Behav. Ecol. Sociobiol. 27, 1 (1990)

51. Heinze, J., Gübitz, T., Errard, C., Lenoir, A., Hölldobler, B.: Experientia 49, 814 (1993)

52. Buschinger, A.: Insectes Soc. 15, 217 (1968)

53. Medeiros, F. N. S., Lopes, L. E., Moutinho, P. R. S., Oliveira, P. S., Hölldobler, B.: Ethology 91, 134 (1992) 
54. Carlin, N. F., Reeve, H. K., Cover, S. P., in: Queen Number and Sociality in Insects, p. 362 (L. Keller, ed.). Oxford: Oxford Univ. Press 1993

55. Peeters, C., Higashi, S.: Naturwissenschaften 76, 177 (1989); Peeters, C., Billen, J., Hölldobler, B.: ibid. 79 , 572 (1992); Peeters, C., Billen, J.: Experientia 47, 229 (1991)

56. Peeters, C., Tsuji, K.: Insectes Soc. 40, 119 (1993); Sommer, K., Hölldobler, B., Rembold, H.: Ethology 94, 162 (1993)

57. Ito, F., Higashi, S.: Naturwissenschaften 78, 80 (1991) Ito, F.: Ethology 95, 126 (1993); Higashi, S., Ito, F., Sugiura, N., Ohkawara, K.: Anim. Behav, 47, 179 (1994)

58. Sommer, K., Hölldobler, B.: Naturwissenschaften 79, 470 (1992)

59. Ross, K. G.: Nature 355, 347 (1992); Keller, L., Ross, K. G.: Science 260, 1107 (1993)

60. Cole, B. J.: Behav. Ecol. Sociobiol 18, 165 (1986)

61. Reeve, H. K., Ratnieks, F. L. W., in: Queen Number and Sociality in Insects, p. 45 (L. Keller, ed.). Oxford: Oxford Univ. Press 1993

62. Peeters, C.: Biol. J. Linn. Soc. 44, 141 (1991)

63. Bourke, A. F. G., Heinze, J.: Phil. Trans. R. Soc. Lond. B (in press)

64. Bourke, A. F. G., van der Have, T. M., Franks, N. R.: Behav. Ecol. Sociobiol. 23, 233 (1988)
65. Nonacs, P., Tobin, J. E.: Evolution 46, 1605 (1992)

66. Keller, L.: Oikos 67, 177 (1993)

67. Wilson, E. O.: Ann. Entomol. Soc. Am. 67, 777 (1974); Bourke, A. F. G.: Anim. Behav. 42, 295 (1991); Proc. R. Soc. Lond. B 255, 55 (1994); Crespi, B. J., in: Cannibalism: Ecology and Evolution Among Diverse Taxa, p. 176 (M. A. Elgar, B. J. Crespi, eds.) Oxford: Oxford Univ. Press 1992

68. Ross, K. G.: Behav. Ecol. Sociobiol. 23, 341 (1988); Am. Nat. 141, 554 (1993)

69. Robinson, G. E.: Nature 362, 126 (1993); Page, R. E., Mitchell, S. D.: Trend Ecol. Evol. 8, 265 (1993)

70. Wilson, D. S., Sober, E.: J. Theor. Biol. 136, 337 (1989)

71. Moritz, R. F. A., Southwick, E. E.: Bees as Superorganisms. Berlin: Springer 1992

72. Page, R. E., Mitchell, S. D., in: PSA 1990, Vol. 2 (A. Fione, M. Forbes, L. Wessels, eds.). East Lansing: Philosophy of Science Association 1990; Kauffman, S. A.: Physica 10D, 145 (1984)

73. Hölldobler, B., Peeters, C., Obermayer, M.: Insectes Soc. 41, 63 (1994)

74. Hamilton, W. D.: Ann. Rev. Ecol. Syst. 3, 193 (1972); Grafen, A.: J. Theor. Biol. 122, 95 (1986)

75. Hölldobler, B., Wilson, E. O.: Journey to the Ants. Cambridge, MA: Belknap Press of Harvard Univ. Press (in press) 